Article

\title{
Application of Cluster Analysis in Marketing Communications in Small and Medium-Sized Enterprises: An Empirical Study in the Slovak Republic
}

\author{
Lenka Ližbetinová $^{1, * \mathbb{C}}$, Peter Štarchoň ${ }^{2}$, Silvia Lorincová ${ }^{3}\left[\right.$, Dagmar Weberová ${ }^{2} \mathbb{C}$ and \\ Petr Průša 4 \\ 1 Faculty of Corporate Strategy, The Institute of Technology and Business in Ceske Budejovice, \\ 37001 Ceske Budejovice, Czech Republic \\ 2 Faculty of Multimedia Communications, Tomas Bata University in Zlín, 76001 Zlín, Czech Republic; \\ starchon@utb.cz (P.Š.); weberova@utb.cz (D.W.) \\ 3 Faculty of Wood Sciences and Technology, Technical University in Zvolen, 96001 Zvolen, Slovakia; \\ silvia.lorincova@tuzvo.sk \\ 4 Jan Perner Transport Faculty, University of Pardubice, 53210 Pardubice, Czech Republic; petr.prusa@upce.cz \\ * Correspondence: lizbetinova@mail.vstecb.cz; Tel.: +420-380-070-226
}

Received: 22 March 2019; Accepted: 15 April 2019; Published: 17 April 2019

\begin{abstract}
Creating an effective marketing strategy according to current trends is a key process needed to achieve sustainable growth that can result in attracting a great number of existing as well as potential customers. Moreover, an enterprise's success is affected by the aforementioned process. The aim of the paper is to determine the clusters of small and medium-sized enterprises operating in the Slovak Republic and the use of marketing communication tools in the future. The research into marketing communications and customer relationship management (CRM) building in companies was carried out in Slovakia in the years 2017 and 2018. In total, 1,009 small and medium-sized enterprises from Slovakia participated in the research. Following a K-means clustering algorithm, three clusters were determined. Descriptive statistics, cluster analysis using K-means clustering, and an analysis of variance (ANOVA) were used to identify no statistically significant difference in terms of the size of enterprises.
\end{abstract}

Keywords: SMEs; marketing communications; marketing communication tools; CRM; customer database; cluster analysis

\section{Introduction and Background}

Small and medium-sized enterprises (SMEs) are considered the key economic drivers in Europe [1]. Significant contribution to gross domestic product, increasing innovative activities, launching a new product in a flexible way, creating jobs, retaining existing jobs and generating overall social growth can be observed [2-10]. In Slovakia, SMEs have a key role in boosting productivity. More than a half of the active labour force contributing to a large extent to the added value is hired by SMEs [11]. SMEs make up $99.9 \%$ of the total number of enterprises in Slovakia; $96.9 \%$ of them are micro-enterprises (with less than 10 employees), $2.5 \%$ are small enterprises and $0.5 \%$ are medium-sized enterprises. In the knowledge economy, innovation ability as well as the sustainability of business processes are key factors for enterprises thriving and withstanding the fierce market competition [12-15]. The business activities of SMEs are affected by the growing trend of globalization putting the pressure on businesses in order to develop effective strategies to succeed in a highly competitive environment [16-19]. In this context, the business strategies of modern enterprises are aimed at achieving sustainable processes $[20,21]$. 
Since the customer relationship management is based on the fact that customer is the main source of enterprise revenue, finding customers, attracting them, meeting their needs, wishes and interests are the keys to sustainable growth and subsequent success [22-32]. Marketing communications are becoming an important part of strategic business management in achieving sustainable development [33-36]. On one hand, it is used to inform employees about performances, to explain the properties, highlight the benefits, quality, value, the use. On the other hand, it provides ability to listen, propose consumers' motions and demands, and deal with them appropriately [37,38].

The traditional mix of marketing communications consisting of advertising, public relations, sales promotion and personal sales is most often used for communication with the customer during the pre-buy, purchase and after-purchase period [39-42]. Advertisements are the most commonly used and most popular marketing communication tools delivering important messages to a large group of consumers faster than any other form of marketing communications [43-45]. While launching a product or promoting products with low consumer interest or almost no interest due to the lack of information or low awareness, using public relations has proven to be useful [46,47]. The marketing communication tool is used in particular because of its huge impact on public opinion. Much lower costs in comparison to standard advertising can be considered a further reason [48]. The number of customers can be increased as well as the particular service being supported by sales promotion. The aim of impersonal communication is to encourage the customer to try to use a particular product or service with temporary benefits or rewards [49]. When the advertising seems to be ineffective, personal sales are used as a more demanding form of promotion by providing information, showing, building long-term relationships, or by persuading certain members of the public [50,51].

New technology developments result in the use new, modern tools of marketing communications [52-55]. Computers, the Internet, mobile phones, radio, television and various types of game consoles are used as communication channels to promote products in the area of digital marketing [56-58]. The growing importance of mobile marketing is caused by mobile phone penetration. Any marketing activity can be carried out by customers by means of their personal mobile devices $[59,60]$. Marketing activities are performed through wireless mobile technology using services such as Short Message Service (SMS), Multimedia Messaging Service (MMS), Wireless Application Protocol (WAP), and third-generation network capabilities [61,62]. Maximum publicity with minimal costs can be achieved through guerrilla marketing highlighting the sensation (unique, original idea proving courage, joke and innovative thinking) not bothering the target customers and, moreover, not harming the public [63-65]. Ambient, i.e., non-standard, alternative media, particularly outdoor media including public transport, benches, bus stops, litter bins, public lighting pillars, public space, shop or restaurant interiors, are used to attract attention of customers [66,67]. Viral marketing when customers provide information about the product, service or website has become very popular as well [67-69]. Event marketing is used in order to build relationships with suppliers, clients and own employees. Organizers of events (concerts and festivals) try to come up with new ideas, beat competitors and attract the customers [58,67]. Product placement, selling, sponsorship, exhibitions, corporate identity, packing, and point-of-sale merchandising are examples of advanced marketing communications [48,70,71].

New opportunities to provide information in a quickly accessible form have been available because of new technology development [72-74]. Consequently, consumers are more demanding, knowledgeable and well informed [75]. They can choose a product taking into account their requirements in terms of price, nutrition, function or value for money, etc. Emphasis is placed not only on the properties, price, quality and delivery conditions, but also on range of sales and after-sales services [76-79]. Increasing customer diversity results in a great variety of new communication tools being implemented [80-84]. Creating an effective marketing strategy according to current trends is a key process needed to achieve sustainable growth that can result in attracting a great number of existing as well as potential customers. Moreover, enterprise success is affected by the aforementioned process as well [85-92]. The introduction of the intelligent system known as Industry 4.0 requires enterprises to adapt to new market demands. Fundamental changes in technological developments are reflected 
in marketing promotion through a form of new communication and virtual channels. Sustainability of SMEs implies a greater use of progressive forms of marketing communications and especially e-marketing tools [93,94]. From this point of view, the attention of researchers in Slovakia is mainly focused on the use, conditions and research on the effectiveness of these electronic forms of marketing communication. Pollák and Dorčák [95] identified the basic prerequisites for the effective use of the Facebook social networking site as a platform for marketing communications for SMEs in Slovakia. Similarly, Hudák et al. [96] in their study tested the marketing elements of an email and provided recommendations for creating an effective marketing email. Several authors mention the results of research studies into specific elements of the Internet and mobile marketing communications [97-99]. In terms of research on applied marketing communications in Slovakia, the results are presented in specific areas such as tourism [100,101], environmental protection [102,103], higher education [104,105], the hotel industry, and others. In general, there is a lack of research focusing on SMEs in Slovakia.

The aim of the paper is to determine the clusters of SMEs operating in the Slovak Republic according to use of the marketing communication tools (current use and plans for future). Uniqueness of the research lies in enhancing the knowledge by looking not only at the current use of marketing communication tools in the environment of small and medium-sized enterprises in Slovakia, but also by viewing the future of the use of marketing communication tools. The classification into clusters brings a new dimension because clusters are created according to the current and planned future use of marketing communication tools. These clusters are then tested for differences in multiple attributes such as enterprise size, majority ownership, territorial scope of marketing activities, the use of an agency to implement marketing programs, the creation of customer database, and the use of a customer relationship management (CRM) system.

\section{Materials and Methods}

The research was focused on marketing communications and CRM building in companies in Slovakia. The research was carried out over the course of the years 2017 and 2018. Representatives of selected companies, responsible for the decision-making process in marketing management and marketing communications, participated in the research. When selecting the respondents, a proportional stratified sampling method was used (regarding the size, location, sector, legal form, major business owner). Business entities registered with the Infostat Company in the Slovak Republic in 2017 were considered the sampling unit. The questionnaire was sent to 1600 selected SMEs by an e-mail or by mail directly to the address of the headquarters or they were addressed personally. At the end of 2017, 257 questionnaires were accepted and 752 questionnaires from SMEs were collected at the beginning of the year 2018. The total number of SMEs filling the questionnaires correctly was 1009 (see Table 1). The sampling unit is presented in Table 1 . The response rate was $63 \%$.

Table 1. Description of sampling unit.

\begin{tabular}{ccccc}
\hline Type of Enterprise & Frequency & Percent & Valid Percent & Cumulative Percent \\
\hline Small enterprise & 869 & 86.10 & 86.10 & 86.10 \\
Medium-sized enterprise & 140 & 13.90 & 13.90 & 100.00 \\
Total & 1009 & 100.00 & 100.00 & \\
\hline
\end{tabular}

Source: Authors' compilation.

The questionnaire consisted of 32 questions aimed at analysing the state-of-the-art of the use of marketing communication mix elements in the enterprises. Furthermore, attitudes towards applying new elements of marketing communications and new media as well as towards the current trends were determined following the questionnaire. Its aim was to identify possible changes in the use of particular elements of the marketing communication mix. Enquiries relating to the creation and use of databases, the implementation of CRM systems, the awareness of the concept of integrated marketing communications and its application in studied enterprises were those of great importance as well. For 
the purpose of this paper, data associated with the use of selected marketing communication tools such as television, radio, print media, point of sales, telephone, mobile, the Internet, cinema and other progressive forms were gathered.

Data were processed using basic descriptive statistics (absolute and relative frequency, arithmetic mean). Subsequently, the cluster analysis of the K-means cluster in SPSS statistics was used to identify clusters. Determining empirical types, segments, and biological clusters is based on identifying sub-clusters with similar vector variable profiles. The procedure follows the Euclidean distance matrices between rows [106]. The aim of the analysis—-to iterate and classify-was selected in order to specify SME groups in the Slovak Republic according to the applied marketing communication tools (variables). Since this method is not invariant to the order of cases, four different clustering solutions (via randomly generated order of cases RU1, RU2, RU3 and RU4 using SPSS statistical program) have been tested in order to obtain appropriate results. Following number of resulting clusters-3, 4, 5, and 6 were also tested. Subsequently, the resulting alternative cluster results were evaluated in terms of composition and preferences in using the marketing communication tools. the option with four resulting clusters in the random arrangement of RU2 presented in Table 2 seems to be the best. A small group of nine cases (Cluster 3), completely different from the total set, are included in the resulting clusters. These cases of small groups are not included in the further analysis [106].

Table 2. Number of cases in each cluster.

\begin{tabular}{cccc}
\hline Cluster & Small Enterprise & Medium-Sized Enterprise & Row Sums \\
\hline $\mathbf{1}$ cluster & & & $21.90 \%$ \\
Absolute frequency & 187 & 34 & 221 \\
Relative frequency & $84.60 \%$ & $15.40 \%$ & $19.03 \%$ \\
\hline $\mathbf{2}$ cluster & & 36 & 192 \\
Absolute frequency & 156 & $18.80 \%$ & $0.89 \%$ \\
Relative frequency & $81.30 \%$ & 0 & 9 \\
\hline 3 cluster & & $0.00 \%$ & $58.18 \%$ \\
Absolute frequency & 9 & & 578 \\
Relative frequency & $0.89 \%$ & 70 & 1009 \\
\hline 4 cluster & 517 & $11.90 \%$ & $100.00 \%$ \\
Absolute frequency & $88.10 \%$ & 140 & \\
Relative frequency & 869 & $13.90 \%$ & \\
\hline Total absolute frequency & $86.10 \%$ & & \\
Total relative frequency & & & \\
\hline
\end{tabular}

Source: Authors' compilation.

Differences in the profiles of created clusters are presented in Table 3. The distance between Cluster 2 and Clusters 3 and 4 is the greatest one. The minimum difference is between Cluster 1 and Cluster 4 (i.e., 2.02 times less than between 2 and 4).

Table 3. Distances between final clusters.

\begin{tabular}{ccccc}
\hline Cluster & $\mathbf{1}$ & $\mathbf{2}$ & $\mathbf{3}$ & $\mathbf{4}$ \\
\hline 1 & & 6.037 & 7.281 & 4.467 \\
2 & - & & 10.172 & 9.063 \\
3 & - & - & & 7.451 \\
4 & symmetric & - & - & \\
\hline
\end{tabular}

Source: Authors' compilation.

Descriptive statistics were used to analyse the resulting clusters. The correlation between formed clusters is tested using analysis of variance (ANOVA). The following hypothesis was determined: 
H1: SMEs representing individual clusters (based on the use of marketing communication tools and their intended use) in terms of selected attributes (enterprise size, majority ownership, territorial scope of marketing activities, agency used in marketing programs, customer database creation, and CRM use) are equal.

\section{Results and Discussion}

The data gathered and processed for the needs of SPSS Statistics were subjected to a cluster analysis of the K-means cluster. An alternative with the four resulting clusters with the random sequence of the RU2 cases was selected by comparing the possible results of the created clusters. Subsequently, these results were tested by ANOVA. The results are presented in Table 4 . However, the significance of the differences does not make sense theoretically and, therefore, testing the hypotheses dealing with ANOVA averages is not possible especially due to the fact that clusters arise in such a way that the vectors differ as much as possible and the significance of differences is supported this way.

Table 4. The analysis of variance (ANOVA) analysis.

\begin{tabular}{|c|c|c|c|c|c|c|c|}
\hline \multirow[b]{2}{*}{ Media } & \multirow{2}{*}{ Marketing Communications Form } & \multicolumn{2}{|c|}{ Cluster } & \multicolumn{2}{|c|}{ Error } & \multirow[t]{2}{*}{ F } & \multirow[t]{2}{*}{ Sig. } \\
\hline & & $\begin{array}{l}\text { Mean } \\
\text { Square }\end{array}$ & df & $\begin{array}{l}\text { Mean } \\
\text { Square }\end{array}$ & df & & \\
\hline \multirow{10}{*}{ Television } & Classic advertising spots & 81.284 & 3 & 0.382 & 1005 & 212.775 & 0.000 \\
\hline & Advertising spots with a direct response & 61.367 & 3 & 0.492 & 1005 & 124.701 & 0.000 \\
\hline & TV program sponsorship & 66.569 & 3 & 0.248 & 1005 & 268.957 & 0.000 \\
\hline & Interviews with company representatives & 46.066 & 3 & 0.358 & 1005 & 128.587 & 0.000 \\
\hline & Interviews & 40.469 & 3 & 0.641 & 1005 & 63.130 & 0.000 \\
\hline & Organizing competitions & 96.056 & 3 & 0.398 & 1005 & 241.057 & 0.000 \\
\hline & Providing prizes to competitions & 127.349 & 3 & 0.406 & 1005 & 313.769 & 0.000 \\
\hline & Product placement & 72.096 & 3 & 0.376 & 1005 & 191.822 & 0.000 \\
\hline & Teleshopping & 39.917 & 3 & 0.124 & 1005 & 321.483 & 0.000 \\
\hline & Teletext & 46.413 & 3 & 0.131 & 1005 & 353.641 & 0.000 \\
\hline \multirow{8}{*}{ Radio } & Classic advertising spots & 116.499 & 3 & 0.421 & 1005 & 276.409 & 0.000 \\
\hline & Advertising spots with a direct response & 102.672 & 3 & 0.307 & 1005 & 334.763 & 0.000 \\
\hline & Program sponsorship & 87.123 & 3 & 0.268 & 1005 & 325.633 & 0.000 \\
\hline & Interviews with company representatives & 51.767 & 3 & 0.358 & 1005 & 144.610 & 0.000 \\
\hline & Interviews & 95.709 & 3 & 0.474 & 1005 & 202.050 & 0.000 \\
\hline & Organizing competitions & 75.106 & 3 & 0.329 & 1005 & 228.165 & 0.000 \\
\hline & Providing prizes to competitions & 124.374 & 3 & 0.278 & 1005 & 446.874 & 0.000 \\
\hline & Product placement & 59.299 & 3 & 0.230 & 1005 & 258.327 & 0.000 \\
\hline \multirow{6}{*}{$\begin{array}{c}\text { Point of } \\
\text { sale }\end{array}$} & Leaflets & 40.128 & 3 & 0.658 & 1005 & 60.958 & 0.000 \\
\hline & Posters & 49.939 & 3 & 0.743 & 1005 & 67.237 & 0.000 \\
\hline & Catalogues & 54.502 & 3 & 0.692 & 1005 & 78.755 & 0.000 \\
\hline & Tasting & 61.108 & 3 & 0.288 & 1005 & 212.157 & 0.000 \\
\hline & Competitions & 100.865 & 3 & 0.504 & 1005 & 200.223 & 0.000 \\
\hline & Presentations & 51.909 & 3 & 0.703 & 1005 & 73.891 & 0.000 \\
\hline \multirow{8}{*}{$\begin{array}{l}\quad \text { Print } \\
\text { (newspapers, } \\
\text { magazines) }\end{array}$} & Desktop advertising (classic) & 62.487 & 3 & 0.679 & 1005 & 92.051 & 0.000 \\
\hline & Desktop advertising with a response & 62.226 & 3 & 0.345 & 1005 & 180.574 & 0.000 \\
\hline & Line advertising & 62.083 & 3 & 0.395 & 1005 & 157.360 & 0.000 \\
\hline & Inserted leaflets & 99.978 & 3 & 0.555 & 1005 & 180.070 & 0.000 \\
\hline & Inserted samples & 75.444 & 3 & 0.217 & 1005 & 348.172 & 0.000 \\
\hline & Public relations (PR) articles & 36.258 & 3 & 0.730 & 1005 & 49.654 & 0.000 \\
\hline & Organizing competitions & 75.991 & 3 & 0.407 & 1005 & 186.885 & 0.000 \\
\hline & Providing prizes to competitions & 94.998 & 3 & 0.476 & 1005 & 199.482 & 0.000 \\
\hline \multirow{4}{*}{ Telephone } & Passive telemarketing & 60.296 & 3 & 0.294 & 1005 & 205.419 & 0.000 \\
\hline & Active telemarketing & 58.988 & 3 & 0.437 & 1005 & 135.000 & 0.000 \\
\hline & Sales over the phone & 48.477 & 3 & 0.482 & 1005 & 100.553 & 0.000 \\
\hline & Organizing competitions & 44.493 & 3 & 0.217 & 1005 & 204.716 & 0.000 \\
\hline \multirow{9}{*}{ Mobile } & Mobile advertising & 81.690 & 3 & 0.283 & 1005 & 288.476 & 0.000 \\
\hline & Bluetooth marketing & 59.691 & 3 & 0.050 & 1005 & 1204.529 & 0.000 \\
\hline & Banners in applications & 69.945 & 3 & 0.311 & 1005 & 225.094 & 0.000 \\
\hline & Mobile apps & 81.223 & 3 & 0.331 & 1005 & 245.484 & 0.000 \\
\hline & Geolocalisation & 59.764 & 3 & 0.135 & 1005 & 442.572 & 0.000 \\
\hline & $\begin{array}{l}\text { Sending short message service (SMS) to } \\
\text { customers }\end{array}$ & 61.569 & 3 & 0.599 & 1005 & 102.810 & 0.000 \\
\hline & $\begin{array}{l}\text { Sending multimedia messaging service (MMS) } \\
\text { to customers }\end{array}$ & 72.361 & 3 & 0.197 & 1005 & 366.746 & 0.000 \\
\hline & Passive telemarketing & 58.921 & 3 & 0.213 & 1005 & 277.030 & 0.000 \\
\hline & Active telemarketing & 62.063 & 3 & 0.311 & 1005 & 199.528 & 0.000 \\
\hline
\end{tabular}


Table 4. Cont.

\begin{tabular}{|c|c|c|c|c|c|c|c|}
\hline \multirow[b]{2}{*}{ Media } & \multirow{2}{*}{ Marketing Communications Form } & \multicolumn{2}{|c|}{ Cluster } & \multicolumn{2}{|c|}{ Error } & \multirow[t]{2}{*}{$\mathbf{F}$} & \multirow[t]{2}{*}{ Sig. } \\
\hline & & $\begin{array}{l}\text { Mean } \\
\text { Square }\end{array}$ & df & $\begin{array}{l}\text { Mean } \\
\text { Square }\end{array}$ & df & & \\
\hline \multirow{18}{*}{ Internet } & Viral marketing & 90.418 & 3 & 0.522 & 1005 & 173.182 & 0.000 \\
\hline & Discussion forums & 59.425 & 3 & 0.651 & 1005 & 91.259 & 0.000 \\
\hline & Contextual advertising & 98.314 & 3 & 0.451 & 1005 & 217.853 & 0.000 \\
\hline & Website & 10.471 & 3 & 0.399 & 1005 & 26.244 & 0.000 \\
\hline & Sponsoring a discussion forum & 56.112 & 3 & 0.221 & 1005 & 253.399 & 0.000 \\
\hline & Direct e-mail & 54.976 & 3 & 0.713 & 1005 & 77.072 & 0.000 \\
\hline & Banners & 53.363 & 3 & 0.700 & 1005 & 76.220 & 0.000 \\
\hline & Blogs & 65.205 & 3 & 0.558 & 1005 & 116.909 & 0.000 \\
\hline & Vlogs & 50.363 & 3 & 0.156 & 1005 & 323.340 & 0.000 \\
\hline & PPC advertising & 60.294 & 3 & 0.427 & 1005 & 141.128 & 0.000 \\
\hline & Content marketing & 48.697 & 3 & 0.422 & 1005 & 115.395 & 0.000 \\
\hline & Native advertising & 36.784 & 3 & 0.244 & 1005 & 151.019 & 0.000 \\
\hline & Affiliate marketing & 60.881 & 3 & 0.203 & 1005 & 299.907 & 0.000 \\
\hline & Search engine optimization (SEO) & 40.226 & 3 & 0.572 & 1005 & 70.271 & 0.000 \\
\hline & Facebook & 23.213 & 3 & 0.624 & 1005 & 37.209 & 0.000 \\
\hline & Instagram & 58.861 & 3 & 0.647 & 1005 & 90.992 & 0.000 \\
\hline & Youtube & 88.188 & 3 & 0.507 & 1005 & 173.832 & 0.000 \\
\hline & Other social media & 61.708 & 3 & 0.353 & 1005 & 174.572 & 0.000 \\
\hline \multirow{3}{*}{ Cinema } & Cinema advertising & 47.540 & 3 & 0.199 & 1005 & 238.407 & 0.000 \\
\hline & Product placement & 44.522 & 3 & 0.087 & 1005 & 511.045 & 0.000 \\
\hline & Film sponsorship & 36.055 & 3 & 0.133 & 1005 & 270.200 & 0.000 \\
\hline \multirow{7}{*}{$\begin{array}{l}\text { Other } \\
\text { forms }\end{array}$} & Organizing events & 49.996 & 3 & 0.760 & 1005 & 65.742 & 0.000 \\
\hline & Co-organizing events & 63.608 & 3 & 0.662 & 1005 & 96.047 & 0.000 \\
\hline & Fairs and exhibitions & 22.792 & 3 & 0.717 & 1005 & 31.773 & 0.000 \\
\hline & Press conferences & 67.109 & 3 & 0.350 & 1005 & 191.499 & 0.000 \\
\hline & Presentation events & 30.318 & 3 & 0.751 & 1005 & 40.355 & 0.000 \\
\hline & Guerrilla marketing & 53.010 & 3 & 0.111 & 1005 & 475.819 & 0.000 \\
\hline & Buzz marketing, WOM & 44.943 & 3 & 0.121 & 1005 & 370.306 & 0.000 \\
\hline
\end{tabular}

Note: Word of mouth (WOM) is oral communication in the context of a consumer's behaviour, used to spread the reputation of the firm, product or service. It is a consumer's personal recommendation or something that is discussed. Items essential in determining clusters are highlighted in bold. Source: Authors' compilation.

The F tests were used for descriptive purposes because the clusters were chosen to maximize the differences between cases in different clusters. The observed significance levels are not corrected and, thus, cannot be interpreted as testing the $\mathrm{H} 1$ hypothesis. When comparing the results of the $\mathrm{F}$ value in Table 4, the highest values are mentioned in the case of communication most involved in defining the resulting groups, the clusters. The use of mobilebluetooth marketing (F value of 1204.529 , contributing 26.24 times more to determining the clusters than the website- the least evaluated item) was the most important factor. The use of product placement, guerrilla marketing, price awarding on radio and mobile geolocalization supported the rise of clusters significantly. Following the methods used, three significantly different clusters of SMEs in Slovakia (traditionalists, progressives and minimalists) were determined in terms of marketing communication tools implemented.

\subsection{Cluster 1-Traditionalists}

Cluster 1 represents $21.9 \%$ of enterprises (whereof $25.8 \%$ are foreign majority owned enterprises), $84.6 \%$ of them are small enterprises (80.2\% domestic and $19.8 \%$ foreign majority owners) and $15.4 \%$ are medium-sized enterprises ( $41.2 \%$ domestic and $58.8 \%$ foreign majority ownership). The impact of implemented marketing communication activities is regional $(51.1 \%)$, nationwide $(33.9 \%)$, and international (14.9\%). That is why, compared to other clusters, the fact that it is a smaller group with the highest number of a foreign majority owner can be seen. The impact of communication activities is especially regional compared to Clusters 2 and 4 . Databases of customers are created by $71.5 \%$ of the traditionalists, but only $68.8 \%$ use them for marketing communications and $14 \%$ for other marketing activities. The CRM system is implemented by $33.9 \%$ while $32 \%$ consider it effective and $65.3 \%$ partially effective.

In terms of using marketing communication tools (Figure 1), it is rather a more conservative group of SMEs with running marketing communication strategy. More traditional forms of marketing 
communications are preferred by them. Television forms of marketing communications are the most often used by the SMEs in Cluster 1. Nowadays, up to $69.7 \%$ use cash prizes in competitions and $14.5 \%$ are planning to do so in the future; $51.6 \%$ of enterprises organize TV competitions; and $50.7 \%$ provide TV talks (17.6\% are planning to do so in the future). More than half of the businesses in this cluster use radio for marketing communications in the form of commercials $(58.8 \%$ and $18.1 \%$ are planning to use this form), talk shows and interviews (57.5\% and 14.5 are planning it in the future); and almost half of businesses provide cash prizes in competitions ( $49.8 \%$ and $22.6 \%$ are planning it). Advertising spread by post is used by more than a half of enterprises (except the form of putting samples in mailboxes) and only a small percentage $(2.7 \%-13.1 \%)$ is planning to use these forms in the future. Leaflets are used by $68.3 \%$, direct mail by $61.1 \%$, and catalogues by $52 \%$.

Considering the point of sale, leaflets are the most commonly used form of advertising $(84.2 \%$ and $5 \%$ are planning it), $58.4 \%$ organize competitions, $56.6 \%$ make presentations and $54.8 \%$ provide catalogues. Tasting (12.2\%) is the form used least in terms of the point of sale. Compared to other clusters, print media advertising $(74.7 \%)$, inserting leaflets $(68.8 \%)$ and providing prizes in competitions $(61.1 \%)$ are the most applied forms. Phone as a communication tool is used by enterprises. $27.1 \%$ of them focus on selling on the phone and $26.2 \%$ use the phone to contact their customers. Passive telemarketing is used only by $13.1 \%$. Future progress of using the phone is planned in the range from $6 \%$ to $10 \%$. Online forms of marketing communications, e.g., websites $(84.2 \%$ and $0.9 \%$ are planning it), profiles on Facebook (81.4\% and $1.8 \%$ are planning it), advertising banners $(54.8 \%)$, direct emails $(51.6 \%)$, Instagram $(45.7 \%)$ and YouTube $(40.7 \%)$ are used by companies in this cluster primarily. This cluster is characterized by the highest rate of the Internet advertising (13.6\%) compared to $9.4 \%$ of enterprises in Cluster 2 and $3.7 \%$ in Cluster 4. Cinema ads are used by the overwhelming majority of companies $(57.5 \%$ and $16.3 \%$ are planning it). Less than half of enterprises invest in billboard advertising (36.7\%, and $7.7 \%$ are planning it) and vehicle advertising (44.8\%, 3.6\% are planning it); $55.7 \%$ organize events, $55.2 \%$ are involved in organizing events, and presentations are held by $52 \%$ of enterprises. More progressive forms such as guerrilla marketing (5.4\%), buzz marketing, or WOM $(4.1 \%)$ are rarely used.

\subsection{Cluster 2-Progressives}

A progressive cluster includes $19.03 \%$ of SMEs (21.9\% foreign majority owned enterprises), whereof $81.3 \%$ are small enterprises $(85.9 \%$ domestic and $14.1 \%$ foreign majority owners) and $18.7 \%$ are medium-sized enterprises ( $44.4 \%$ domestic and $54.6 \%$ foreign majority owners). Therefore, the impact of the implemented marketing communication activities is regional $(39.6 \%)$, nationwide $(39.1 \%)$ and international (21.4\%). In fact, national and international impact of communication marketing activities is larger than in Clusters 1 and 4 . A customer database is created by only $56.3 \%$ of the progressives, whereby only $55.2 \%$ of them use it for marketing communications and $17.2 \%$ for other marketing activities. A CRM system is implemented in $40.6 \%$ of the enterprises, and $56.4 \%$ consider it to be effective while $41 \%$ think it is only partially effective. 


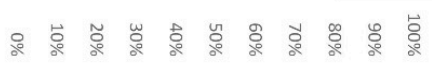

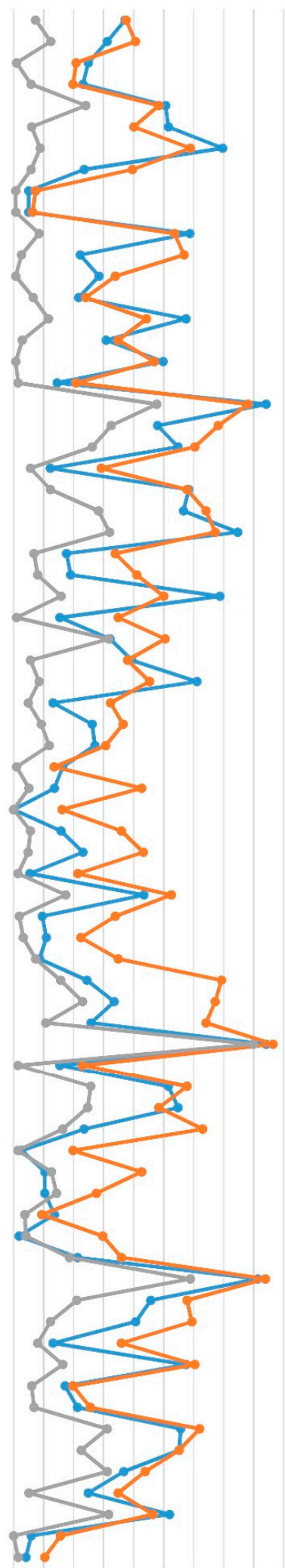

Currently used
Classic advertising spots

Advertising spots with a direct response

TV Program sponsorship

Interviews with company representatives

Interviews

Organizing competitions

Providing prizes to competitions

Product placement

Teleshopping

Teletext

Classic advertising spots

Advertising spots with a direct response

Program sponsorship

terviews with company representatives

Interviews

Organizing competitions

Providing prizes to competitions

Product placement

Leaflets

Posters

Catalogs

Tasting

Competitions

Presentations

Desktop advertising (classic)

Desktop advertising with a response

Line advertising

inserted leaflets

Inserted samples

PR articles

Organizing competitions

Providing prizes to competitions

Passive telemarketing

Active telemarketing

Sales over the phone

Organizing competitions

Mobile advertising

Bluetooth marketing

Banners in applications

Mobile apps

Geolocalisation

Sending short message service (SMS) to customers

Sending multimedia messaging service (MMS) to..

Passive telemarketing

Active telemarketing

Viral marketing

Discussion forums

Contextual advertising

Website

Sponsoring a discussion forum

Direct e-mail

Banners

Blogs

PPC advertising

Content marketing

Native advertising

Affiliate marketing

Search engine optimization (SEO)

Facebook

Instagram

Youtube

Other social media

Cinema advertising

Product placement

Film sponsorship

Organizing events

Co-organizing events

Fairs and exhibitions

Press conferences

Presentation events

Guerrilla marketing

Buzz marketing, WOM

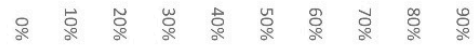
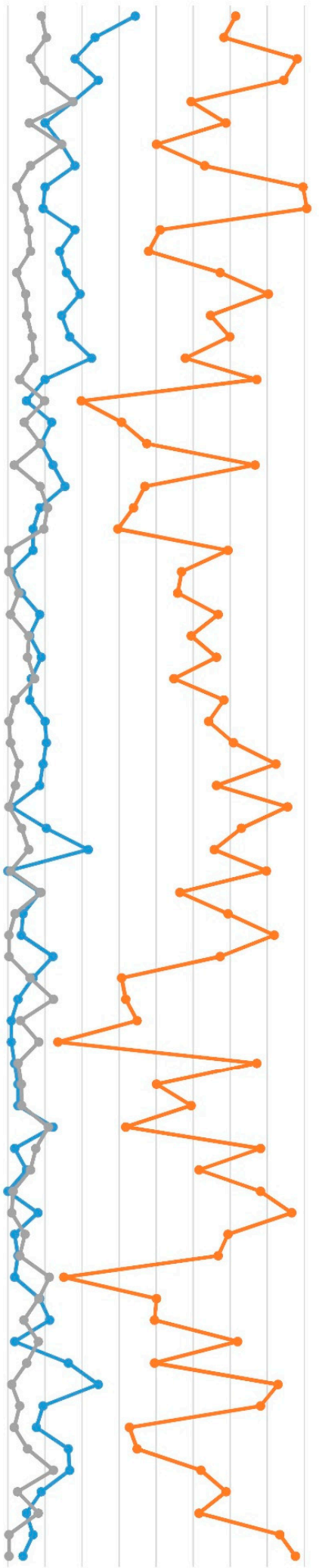

Planning to use

Figure 1. Use and planned use of marketing communication tools by small and medium-sized enterprises (SMEs). 
A wide range of communication tools is used by the members of Cluster 2 (Figure 1). However, in comparison to Cluster 1, Progressives prefer mobile, online and more progressive forms of communication tools and their plans and visions dealing with the future of media are ambitious. The use of TV for marketing purposes is less important than in Cluster 1, however, they are planning to use it especially in the future. Similarly to Cluster 1, prizes in TV competitions are provided by most enterprises (58.9\% and $40.1 \%$ are planning to do it in the future). Talk shows are provided by $48.4 \%$ ( $49.5 \%$ are planning to do it in the future), and $40.6 \%$ use TV (direct-response advertising spots), and $58.3 \%$ of them are planning to implement this form into marketing communications in the future. Radio, e.g., ad spots with a direct response (including the phone number, website, or email), is preferred by more than half of enterprises in this cluster, $56.8 \% ; 38 \%$ enterprises are planning to do so in the future. Moreover, $53.6 \%$ use it for classic advertising spots and $41.1 \%$ are planning to do so in the future. Beside the use of the aforementioned forms of radio communication, this group of SMEs has high aspirations for its implementation in the future (up to $70.3 \%$ are planning to send their representatives to radio sessions). Mailing as a marketing tool is widely used by these enterprises; leaflets are used by $71.9 \%$ of these enterprises, direct offers by $75.5 \%$ and catalogues by $62.5 \%$, while $36.5 \%$ are planning to take advantage of postal services in the future. Sending samples is used by $35.4 \%$ and $57.8 \%$ are planning to do so in the future. The forms of communication at the point of sale are used by most members of this cluster, $78.1 \%$ of them are using leaflets $(19.8 \%$ are planning to use them), $68.2 \%$ are using advertising banners and $30.7 \%$ are planning to use them, and $57.8 \%$ are using competitions. Compared to Cluster 1, space advertising, leaflets and prizes in competitions are used the enterprises in this cluster to a lesser extent. On the other hand, aspirations for their future implementation is relatively high, from $29.7 \%$ to $45.8 \%$. Similarly, it is also high in the case of other forms of print media strongly used in the group. A landline for marketing communications is most often used by members of the Cluster 2, moreover, the members still not using it are planning to change it in the near future. Active customer contact is used by $36.5 \%$, passive telemarketing by $32.3 \%$, and sales on the phone is carried out by $30.7 \%$ of enterprises. This group of SMEs uses Internet communications (except for native advertising) most of all. A high percentage is planning to use them. Similar to other clusters, websites $(86.5 \%$ and $13.5 \%$ are planning them) and Facebook profiles $(83.9 \%$ and $15.1 \%$ is planning them) are the most used forms. Attention is also paid to viral marketing $(69.3 \%$ and $30.7 \%$ are planning to use it), as well as to discussion forums (67.2\% and $31.8 \%$ are planning them) and contextual advertising (64.1\% and $34.9 \%$ are planning this). The enterprises in this cluster use and, in particular, are planning to use even less common forms such as content and affiliate marketing, SEO, vlogs and blogs. It is the group of companies using (or it is planning to use) cinema for marketing communications most, e.g., cinema ads $(60.4 \%$ and $39.6 \%$ are planning to do so), sponsorship $(25.5 \%$ and $68.2 \%$ are planning to do so) and product placement (19.8\% and $72.9 \%$ are planning to do so in the future). Considering outdoor advertising, this group invests most and is planning to invest in stands (60.4\% and $33.3 \%$ are planning), vehicle advertising (52.6\% and $43.2 \%$ are planning) and billboards (37.5\% and $52.6 \%$ are planning this investment). More than three quarters of enterprises in this cluster $(77.6 \%)$ are planning to invest in ambient media. According to the other media used, the fact that this group does not only use but it also prefers using more progressive forms in the future, e.g., guerrilla marketing, as well as buzz marketing can be seen (15.6\% of enterprises has already used them and $73.4 \%$ are planning to use them in the future. WOM is used by $10.4 \%$ of enterprises and $77.6 \%$ are planning to do so in the future; $62 \%$ organize and $32.8 \%$ are planning to organize events, and $55.2 \%$ are involved in organizing the events. In addition, presentations are held by $46.4 \%$ of enterprises.

\subsection{Cluster 4-Minimalists}

Cluster 4 is represented by $58.18 \%$ of enterprises (whereof $86.7 \%$ are domestic majority owners) and it consists of small enterprises (88.1\%). In the case of $91.1 \%$ of them, the majority of owners are domestic and in the case of $8.9 \%$ the majority of owners are foreign. When medium-sized companies $(11.9 \%)$ are mentioned, $54.3 \%$ of them have domestic and $45.7 \%$ foreign majority owners. The impact 
of implemented marketing communication activities is regional $(46.2 \%)$, nationwide $(35.4 \%)$, and international $(18.4 \%) ; 84.5 \%$ of the minimalists create customer databases, but only $60.8 \%$ use them for marketing communications, and $12.4 \%$ for other marketing activities. Similar to Cluster 1, 33.9\% has a CRM system. However, $47.7 \%$ of enterprises in this cluster consider it effective and $32.7 \%$ partially effective.

Marketing communications is not emphasised by this group of SMEs (Figure 1). However, they use marketing communication tools but only to a lesser extent. Websites and Facebook profiles are the most used forms. When investing in marketing communications, they prefer the following media: post office, point of sale, print, the Internet and organized and co-organized events, or exhibitions and fairs. Communication tools are not used by this group very often, moreover, they are not planned to be used in the future as well. TV and radio, landline, mobile, or outdoor advertising are implemented by these SMEs only rarely. In terms of point of sale, leaflets are used by $47.7 \%$ of enterprises, advertising banners by $35.5 \%$ and space advertising by $32 \%$. Compared to other clusters, the fact that online marketing communication is the least used form in this group can be stated. These enterprises use only websites (79.9\% and $8.3 \%$ are planning to do so) and Facebook profiles (58.9\% and $11.2 \%$ are planning to do so in the future). The use of other forms of online marketing communication does not exceed $26 \%$. Similar to other marketing tools, cinema is the least used or planned alternative by this group. Pre-release commercials are used by $16.4 \%$ of enterprises while other forms are not used very often. In the case of outdoor advertising, these enterprises pay the highest attention to vehicle advertisements $(16.5 \%)$ while $12.1 \%$ of them focus on stands. The planning of future investments in outdoor advertising is almost none. Taking into consideration other forms of marketing communications, the fact that $31.2 \%$ of these enterprises organize events and participate in fairs and exhibitions (12.3\% are planning to do so in the future) can be seen. Presentations are organized by $31.7 \%$ of enterprises.

Due to the composition of determined clusters, the dependence of several attributes, such as enterprise size, majority ownership, the territorial scope of marketing activities, agency used in marketing programs, customer database creation, and CRM were verified by ANOVA. Following the one-way ANOVA with the p-value smaller than 0.05 at the significance level of $5 \%$, a significant difference in clusters was confirmed in terms of the majority owner of the enterprise (Table 5), the territorial scope of marketing communication programs (Table 6), the use of agency services for the implementation of marketing programs (Table 7), the creation of customer databases (Table 8), and the use of the CRM system (Table 9). Thus, the H0 claiming the given attribute is the same in the clusters was rejected in favour of the alternative hypothesis. By contrast, the size of the enterprise (Table 10) is not statistically significantly different comparing individual clusters. It is confirmed by the Anova test result, where $\mathrm{p}$ value is 0.56 .

Table 5. ANOVA analysis of clusters vs. the majority owner of the company.

\begin{tabular}{cccccc}
\hline & Sum of Squares & df & Mean Square & F & Sig. \\
\hline Between Groups & 3.204 & 3 & 1.068 & 7.519 & 0.000 \\
Within Groups & 142.747 & 1005 & 0.142 & & \\
Total & 145.950 & 1008 & & & \\
\hline
\end{tabular}

Source: Authors' compilation.

Table 6. ANOVA analysis of clusters vs. the territorial scope of marketing communication programs.

\begin{tabular}{cccccc}
\hline & Sum of Squares & df & Mean Square & F & Sig. \\
\hline Between Groups & 7.968 & 3 & 2.656 & 4.754 & 0.003 \\
Within Groups & 561.398 & 1005 & 0.559 & & \\
Total & 569.366 & 1008 & & & \\
\hline
\end{tabular}

Source: Authors' compilation. 
Table 7. ANOVA analysis of clusters vs. the use of an agency implementing the marketing communication program.

\begin{tabular}{cccccc}
\hline & Sum of Squares & df & Mean Square & F & Sig. \\
\hline Between Groups & 8.626 & 3 & 2.875 & 3.631 & 0.013 \\
Within Groups & 795.935 & 1005 & 0.792 & & \\
Total & 804.561 & 1008 & & \\
\hline
\end{tabular}

Source: Authors' compilation.

Table 8. ANOVA analysis of clusters vs. creating a customer database.

\begin{tabular}{cccccc}
\hline & Sum of Squares & df & Mean Square & F & Sig. \\
\hline Between Groups & 18.712 & 3 & 6.237 & 17.763 & 0.000 \\
Within Groups & 352.890 & 1005 & 0.351 & & \\
Total & 371.602 & 1008 & & & \\
\hline
\end{tabular}

Source: Authors' compilation.

Table 9. ANOVA analysis of clusters vs. implemented customer relationship management (CRM) system.

\begin{tabular}{cccccc}
\hline & Sum of Squares & df & Mean Square & F & Sig. \\
\hline Between Groups & 10.230 & 3 & 3.410 & 6.444 & 0.000 \\
Within Groups & 531.786 & 1005 & 0.529 & & \\
Total & 542.016 & 1008 & & \\
\hline \multicolumn{5}{c}{ Source: Authors' compilation. }
\end{tabular}

Table 10. ANOVA analysis of clusters vs. enterprise size.

\begin{tabular}{cccccc}
\hline & Sum of Squares & df & Mean Square & F & Sig. \\
\hline Between Groups & 0.903 & 3 & 0.301 & 2.528 & 0.056 \\
Within Groups & 119.672 & 1005 & 0.119 & & \\
Total & 120.575 & 1008 & & & \\
\hline
\end{tabular}

Source: Authors' compilation.

The $\mathrm{H} 1$ hypothesis is confirmed in the case of the attribute of enterprise size. In the case of the attributes of majority ownership, the territorial scope of marketing activities, agency used in marketing programs, customer database creation and CRM use, the $\mathrm{H} 1$ hypothesis was refused in favour of alternative one.

Following the research results, the fact that all companies use TV, radio, print media, mobile devices, the Internet, as well as outdoor and indoor advertising can be stated.

A marketing communication survey was carried out by Starchon and Vilcekova [107] in 2007 and 2017. More than 300 enterprises participated in this research and the findings reflect changes in communication behaviour. For example, an increase in consumer contests can be observed. According to this study, in 2007, this tool was used only by $16 \%$ of enterprises. Compared to the year 2017, it was more than $33 \%$ of the studied enterprises. An overall growth can be observed in the intensity of using different tools including television. Starchon and Vilcekova [107] mentioned that in 2007, 23\% of companies used TV commercials while in 2017 it was 34\%. While advertising in print media has a general tendency to decline, an increase in PR activities can be seen. Unsurprisingly, the biggest change can be noticed in using the new media. An increase of $13 \%$ can be observed in content marketing (7\% in 2007 compared to 19\% in 2017). The huge increase can be seen in the use of social media. In 2007, only 7\% of enterprises used this tool while in 2017 it was 75\% [107]. In Slovakia, most of the enterprises use Facebook, Instagram and YouTube to communicate with their customers. SMEs represent a significant part of Slovak economy with the greatest potential for growth and the impact 
on economic stabilization and balanced development of the regions [108-112]. In Slovakia, 99.9\% of the total number of business entities are SMEs and in 2017, they recorded increased employment $(+1.4 \%)$, added value $(+8.9 \%)$, or profit $(+7.5 \%)$, while value added growth in this sector was the most significant over the course of the last seven years [12]. In the competitive market, SMEs are vulnerable and exposed to many risks but their existence and success are of great importance in the Slovak Republic. Therefore, the aim of the study is to support companies by helping them make the right decision about developing suitable marketing communication programs using adequate communication tools and selecting appropriate media.

Pohludka and Štverková [108] present the results of the research focused on the use of CRM in SMEs in the Czech Republic carried out using a sample of 319 business entities. Following their research, the fact that, similarly to the enterprises in Slovakia, there is a significant gap between companies creating customer databases $(81 \%)$ and subsequently using the data within a CRM $(45 \%)$ can be seen. Collecting customer data does not mean that a CRM is implemented in the enterprise. A CRM philosophy is a prerequisite for an enterprise to collect customers' data and cooperate with them.

When verifying the CRM implementation in the studied enterprises, the fact that $45 \%$ of entities have a CRM system, $3 \%$ are in the implementation phase; $21 \%$ consider implementation and $31 \%$ of respondents do not consider implementing CRM was found. In particular, micro-businesses do not think about a CRM system implementation. Taking a closer look at the medium-sized enterprises, $80 \%$ of the studied entities have already implemented the CRM system. These results are comparable to those found in SMEs in Slovakia, where $75.5 \%$ of SMEs create customer databases and only $40.7 \%$ of them use them for the purpose of CRM. In 2012, Urdzikova et al. [113] presented the results of the use of CRM by manufacturing companies in Slovakia. At that time, $0.1 \%$ of micro, $40 \%$ of small and $40 \%$ of medium manufacturing enterprises (in total 262 manufacturing enterprises were analysed) used CRM. Therefore, the further research problem about the use of CRMs and the creation of databases in terms of individual segments arises.

\section{Conclusions}

Entrepreneurial activities are affected by many external factors. Under the pressure of a global competitive environment, businesses have to create sophisticated business strategies. The effect of the upcoming Industry 4.0 is similar. An active use of advanced information technology in the business environment is at the centre of attention. Sustainability is an important part of strategic business management. It can be achieved through effective marketing communications taking into account current trends. The sustainability in marketing communications employed within SMEs depends largely on the level of innovation reflected in the use of modern electronic tools. On the other hand, there is a range of limitations in marketing communication activities of SMEs resulting from restricted finances as well as from the fact that owners and employees of SMEs tend to be generalists rather than specialists, so their marketing expertise is often limited. This brings us to the conclusion that in order to succeed in both domestic and international markets, innovations must be not only at the manufacturing or service level but also in adopting creative and innovative marketing communication activities and in selecting appropriate and adequate marketing communication tools. The aim of the paper was to present the clusters created by the use of marketing communication tools in SMEs. Following the use of a K-means cluster analysis, three clusters significantly different in terms of the majority of owners of an enterprise, the territorial scope of marketing activities, the use of the agency in implementing marketing programs, customer database creation and the use of the CRM system were determined. In terms of enterprise size, these clusters are comparable. The attitude to the previously established and used communication programs applied in the group with the largest foreign ownership was the main difference in the use of marketing tools. Compared to other clusters, TV and radio media were used more frequently. Similarly, the group of enterprises in Cluster 4, the "Minimalists" over-represented within SMEs (formed by $58.18 \%$ of SMEs whereof $88.1 \%$ are small enterprises), is comparably traditional. Minimalistic marketing communication activities in terms of 
marketing tools are preferred by these enterprises. Following the research results, they are not planning to change significantly this trend in the future. Their attention is focused on using the websites, Facebook profiles, leaflets, general advertising, organizing events and presentations or participating in exhibitions and fairs. This group consists mostly of small businesses with close relationship with customers. Their customer database is the largest one (up to 84.5 , by $13 \%$ more than in the case of the Traditionalists (Cluster 1) and by $28.2 \%$ more than the Progressives (Cluster 2). Moreover, a majority of them use the databases for marketing communications. The progressive members of Cluster 2-the "Progressives"-are the most different group of enterprises. They are active in the use of communication tools and prefer forms that are more progressive. Their vision of incorporating forms of communication tools in the future is highly ambitious. This is a group with higher domestic representation, whose marketing activities are rather national or even international. Their visions and real use of marketing communication tools are in contrast with the number of customer databases created. Only $55.2 \%$ of enterprises in this group create databases at the same time. However, these enterprises use the CRM system most (up to $40.6 \%$ ).

The results of this empirical study conducted in SMEs in Slovakia enhance knowledge about the use of marketing communication tools in firms. It provides a valuable view into the presence and implementation of marketing activities as well as the choice of media in promotional campaigns. Most of the budget allocated for marketing communications is spent especially on traditional media such as broadcast (TV and radio) and print media. However, in Slovakia, a tendency to invest in marketing communication activities in new media (the Internet and mobile) has been steadily increasing since the beginning of the 21st century. The Internet and the widespread use of social media have become effective and profitable tools of promoting company products and services. In the case of SMEs, they take advantage of social media because of cost effectiveness, time saving and engagement with customers.

Sustainable development at the SME level is essential and inevitable. The 4.0 Industry Revolution is accompanied by the expectations and demands of customers in the intelligent use of information technology in marketing communications as well as its connection with integrated marketing communications. From this point of view, Cluster 2 (the "Progressives") enterprises are the most responsive to this transition. Nowadays, they are no longer satisfied with websites (86.5\%) and social networks $(83.9 \%)$, but they focus also on viral marketing (69.3\%), contextual advertising and, to a lesser extent, on the use of SEO, vlogs and blogs, buzz marketing, and e-WOM, etc. Cluster 1 (Traditionalists) has no problem with the more common forms of e-marketing communication tools (websites, social networks, native internet advertising, banner ads, direct-mails), however, buzz marketing and e-WOM are almost unused by them.

The transition to Industry 4.0 will be the biggest challenge facing the largest cluster, Cluster 4 (the "Minimalists"). These small enterprises are primarily focused on personal approach to customers. However, the benefits of information technology are not excluded. Without taking advantage of the benefits provided by information technology in marketing, there is a risk that customers will begin to favour competition. Using CRM and e-WOM offers a great advantage to these businesses in order to improve their personal approach and strong customer relationships. SMEs should realize the importance of WOM and e-WOM marketing. Customers' comments as well as experience shared in social networks can strengthen or, on the other hand, destroy the reputation of an enterprise. The more consumers chat and write online about the company, its products and services in a positive way, the better promotion of the enterprise and its performance.

Author Contributions: Conceptualization, L.L., P.Š., S.L., D.W. and P.P.; methodology, L.L., P.Š., S.L., D.W. and P.P.; data curation, L.L., P.Š., S.L., D.W. and P.P.; writing-original draft preparation, L.L., P.Š., S.L., D.W. and P.P.; visualization, L.L., P.Š., S.L., D.W. and P.P. 
Acknowledgments: This research was supported by VEGA 1/0024/17 "Computational model of motivation", VEGA 1/0320/17 "Economic and Social Context of European 20/20/20 Targets from the Viewpoint of Economy Low-energy Houses", APVV 16-0297 “Updating of anthropometric database of Slovak population", TAČR - ÉTA -project TL02000559 Safe and secure cities for pedestrians and senior citizens and TL02000017 Inter-generation cooperation in digitalization.

Conflicts of Interest: The authors declare no conflict of interest.

\section{References}

1. Kazmir, S.A.Z.; Naaranoja, M. Inspiring European small and medium enterprise (SME) sector by inserting effective business transfer process. In Proceedings of the AHFE International Conference on Human Factors, Business Management and Society, Orlando, FL, USA, 21-25 July 2018.

2. Bojica, A.M.; Estrada, I.; del Mar Fuentes-Fuentes, M. In good company: When small and medium-sized enterprises acquire multiplex knowledge from key commercial partners. J. Small Bus. Manag. 2018, 56, 294-311. [CrossRef]

3. Stoian, M.C.; Dimitratos, P.; Plakoyiannaki, E. SME internationalization beyond exporting: A knowledge-based perspective across managers and advisers. J. World Bus. 2018, 53, 768-779. [CrossRef]

4. Bartakova, G.P.; Gubiniova, K.; Brtkova, J.; Hitka, M. Actual trends in the recruitment process at small and medium-sized enterprises with the use of social networking. Econ. Ann.-XXI 2017, 164, 80-84. [CrossRef]

5. Sawang, S.; Parker, R.; Hine, D. How small business advisory program delivery methods (collective learning, tailored, and practice-based approaches) affect learning and innovation. J. Small Bus. Manag. 2016, 54, 244-261. [CrossRef]

6. Gejdoš, M.; Danihelová, Z. Valuation and timber market in the Slovak Republic. Procedia Econ. Financ. 2015, 34, 697-703. [CrossRef]

7. Hitka, M.; Zavadska, Z.; Jelacic, D.; Balazova, Z. Qualitative indicators of company employee satisfaction and their development in a particular period of time. Drv. Ind. 2015, 66, 235-239. [CrossRef]

8. McCann, M.; Barlow, A. Use and measurement of social media for SMEs. J. Small Bus. Enterp. Dev. 2015, 22, 273-287. [CrossRef]

9. Higón, D.A.; Driffield, N. Exporting and innovation performance: Analysis of the annual small business survey in the UK. Int. Small Bus. J. 2011, 29, 4-24. [CrossRef]

10. Dennis, W.J., Jr. Entrepreneurship, small business and public policy levers. J. Small Bus. Manag. 2011, 49, 149-162. [CrossRef]

11. SBA. Malé a stredné podnikanie v číslach v roku 2017. Available online: https://www.npc.sk/file?uuid= b40742be-ac93-4fd0-ae60-b52467626139 (accessed on 27 November 2018).

12. Cornett, M.M.; Erhemjamts, O.; Tehranian, H. Competitive environment and innovation intensity. Glob. Financ. J. 2019, 41, 44-59. [CrossRef]

13. Li, S.; Han, S.; Shen, T. How can a firm innovate when embedded in a cluster?-Evidence from the automobile industrial cluster in China. Sustainability 2019, 11, 1837. [CrossRef]

14. Korauš, A.; Mazák, M.; Dobrovič, J. Quantitative analysis of the competitiveness of Benelux countries. Entrep. Sustain. 2018, 5, 1069-1083. [CrossRef]

15. Hitka, M.; Vetrakova, M.; Balazova, Z.; Danihelova, Z. Corporate culture as a tool for competitiveness improvement. Procedia Econ. Financ. 2015, 34, 27-34. [CrossRef]

16. Bayraktar, C.A.; Hancerliogullari, G.; Cetinguc, B.; Calisir, F. Competitive strategies, innovation, and firm performance: An empirical study in a developing economy environment. Technol. Anal. Strateg. Manag. 2017, 29, 38-52. [CrossRef]

17. Klaric, K.; Greger, K.; Klaric, M.; Andric, T.; Hitka, M.; Kropivsek, J. An exploratory assessment of FSC chain of custody certification benefits in Croatian wood industry. Drv. Ind. 2016, 67, 241-248. [CrossRef]

18. Pratistha, B. The influence of strategic control, strategy orientation, and business environment on competitive strategy and its effect to business performance. Acad. Strateg. Manag. J. 2016, 15, 15-23.

19. Hitka, M.; Potkany, M.; Sirotiakova, M. Proposal of assessment of wood processing company employees. Drew.-Wood 2009, 182, 91-102.

20. Dominguez, N. SME Internationalization Strategies: Innovation to Conquer New Markets; Wiley Backwell: Malden, MA, USA, 2018. 
21. Graa, A.; Abdelhak, S. A review of branding strategy for small and medium enterprises. Acta Oeconomica Univ. Selye 2016, 5, 67-72.

22. Agrawal, S.R.; Mittal, D. Measuring CRM effectiveness in Indian stock broking services. J. Glob. Inf. Manag. 2019, 27, 144-164. [CrossRef]

23. Fróis, J.; Teresa Pereira, M.; Ferreira, F.A. How a CRM tool can contribute to a better business performance: The case of a shipping company. In Proceedings of the 3rd Conference on Innovation, Engineering and Entrepreneurship, Regional HELIX 2018, Guimaraes, Portugal, 27-29 June 2018.

24. Minh Ngo, V.; Pavelkova, D.; Phu Thi Phan, Q.; Van Nguyen, N. Customer relationship management (CRM) in small and medium tourism enterprises: A dynamic capabilities perspective. Tour. Hosp. Manag. 2018, 24, 63-86. [CrossRef]

25. Belz, F.M.; Binder, J.K. Sustainable entrepreneurship: A convergent process model. Bus. Strategy Environ. 2017, 26, 1-17. [CrossRef]

26. Lengler, J.F.B.; Sousa, C.M.P.; Perin, M.G.; Sampaio, C.H.; Martínez-López, F.J. The antecedents of export performance of Brazilian small and medium-sized enterprises (SMEs): The non-linear effects of customer orientation. Int. Small Bus. J. Res. Entrep. 2016, 34, 701-727. [CrossRef]

27. Newby, M.; Nguyen, T.H.; Waring, T.S. Understanding customer relationship management technology adoption in small and medium-sized enterprises: An empirical study in the USA. J. Enterp. Inf. Manag. 2014, 27, 541-560. [CrossRef]

28. Kwok, L.; Yu, B. Spreading social media messages on Facebook: An analysis of restaurant business-to-consumer communications. Cornell Hosp. Q. 2013, 54, 84-94. [CrossRef]

29. Brammer, S.; Jackson, G.; Matten, D. Corporate social responsibility and institutional theory: New perspectives on private governance. Socio-Econ. Rev. 2012, 10, 3-28. [CrossRef]

30. Crittenden, V.L.; Crittenden, W.F.; Ferrell, L.K.; Ferrell, O.C.; Pinney, C.C. Market-oriented sustainability: A conceptual framework and propositions. J. Acad. Mark. Sci. 2011, 39, 71-85. [CrossRef]

31. Jones, R.; Rowley, J. Entrepreneurial marketing in small businesses: A conceptual exploration. Int. Small Bus. J. 2011, 29, 25-36. [CrossRef]

32. Arvidsson, S. Communication of corporate social responsibility: A study of the views of management teams in large companies. J. Bus. Ethics 2010, 96, 339-354. [CrossRef]

33. Kubeš, V.; Rančák, J. Sustainability of organization performance via management techniques. Entrep. Sustain. 2018, 5, 1031-1042. [CrossRef]

34. Amran, A.; Ooi, S.K.; Mydin, R.T.; Devi, S.S. The Impact of business strategies on online sustainability disclosures. Bus. Strategy Environ. 2015, 24, 551-564. [CrossRef]

35. Ashley, C.; Tuten, T. Creative strategies in social media marketing: An exploratory study of branded social content and consumer engagement. Psychol. Mark. 2015, 32, 15-27. [CrossRef]

36. Hultman, M.; Katsikeas, C.S.; Robson, M.J. Export promotion strategy and performance: The role of international experience. J. Int. Mark. 2011, 19, 17-39. [CrossRef]

37. Nyvlt, V. The role of managing knowledge and information in BIM implementation processes in the Czech Republic. In Proceedings of the 9th International Scientific Conference on Building Defects, East Java, Indonesia, 23-24 November 2018. [CrossRef]

38. Lee, Y.C. Corporate Sustainable Development and Marketing Communications on Social Media: Fortune 500 Enterprises. Bus. Strategy Environ. 2017, 26, 569-583. [CrossRef]

39. Khúlová, L. Marketing mix of internationally active company in terms of transport and logistics (export to the USA and China). Acta Oeconomica Univ. Selye 2016, 5, 85-95.

40. Oblak, L.; Glavonjić, B. A model for the evaluation of radio advertisements for the sale of timber products. Drv. Ind. 2014, 65, 303-308. [CrossRef]

41. Boso, N.; Cadogan, J.W.; Story, V.M. Complementary effect of entrepreneurial and market orientations on export new product success under differing levels of competitive intensity and financial capital. Int. Bus. Rev. 2012, 21, 667-681. [CrossRef]

42. Armario, J.M.; Ruiz, D.M.; Armario, E.M. Market orientation and internationalization in small and medium-sized enterprises. J. Small Bus. Manag. 2008, 46, 485-511. [CrossRef]

43. Bonerjee, S.; Mandal, K. Advertisement vs societal based marketing communication: An empirical analytic comparison vis-a-vis profit contribution. Indian J. Mark. 2018, 48, 7-21. [CrossRef]

44. Grimaldi, J. The Art of Advertising; Aspatore: Eagan, MN, USA, 2003. 
45. Hanuláková, E. Etika v Marketingu; Eurounion: Bratislava, Slovakia, 1996.

46. Llopis-Amorós, M.P.; Gil-Saura, I.; Molina, M.E.R. The role of marketing communications in generating brand equity for an event. Event Manag. 2018, 22, 825-848. [CrossRef]

47. Šimo, D. Agrárny Marketing; SPU: Nitra, Slovakia, 2006.

48. Kita, J. Marketing; Ekonóm: Bratislava, Slovakia, 2000.

49. Medved, J.; Kováčová, Z. Finančný a Bankový Marketing; SPRINT: Bratislava, Slovakia, 2003.

50. ̌ad'o, J.; Petrovičová, J.; Kostková, M. Marketing Služieb; EPOS: Bratislava, Slovakia, 2006.

51. Pelsmacker, P.; Geuens, M.; Van den Bergh, J. Marketingová Komunikace; Grada Publishing: Praha, Czech Republic, 2003.

52. Bazhan, M.; Naser, K.; Nastaran, K.M.; Hedayat, H.; Hassan, E.Z.; Hamid, A. Applying social marketing mix to identify consumers' preferences towards functional dairy products in Iran. Nutr. Food Sci. 2018, 48, 45-60. [CrossRef]

53. Potkany, M.; Hitka, M.; Krajcirova, L. Life cycle cost calculation at the transport company in the supply of production of wooden houses-Case Study. Web Conf. 2017, 134. [CrossRef]

54. El Baz, J.; Laguir, I.; Marais, M.; Staglianò, R. Influence of national institutions on the corporate social responsibility practices of small- and medium-sized enterprises in the food-processing industry: Differences between France and Morocco. J. Bus. Ethics 2016, 134, 117-133. [CrossRef]

55. Ainin, S.; Parveen, F.; Moghavvemi, S.; Jaafar, N.I.; Shuib, N.L.M. Factors influencing the use of social media by SMEs and its performance outcomes. Ind. Manag. Data Syst. 2015, 115, 570-588. [CrossRef]

56. Ďurišová, M.; Falát, L.; Malichová, E. The influence of business intelligence on digital marketing and the economic situation of the enterprise. In Proceedings of the International Scientific Conference Marketing Identity: Digital Life, Smolenice, Slovakia, 10-11 November 2015.

57. Kim, Y.; Briley, D.A.; Ocepek, M.G. Differential innovation of smartphone and application use by sociodemographics and personality. Comput. Hum. Behav. 2015, 44, 141-147. [CrossRef]

58. Frey, P. Marketingová Komunikace: To Nejlepší z Nových Trendi̊; Management Press: Praha, Czech Republic, 2008.

59. Tarute, A.; Nikou, S.; Gatautis, R. Mobile application driven consumer engagement. Telemat. Inform. 2017, 34, 145-156. [CrossRef]

60. Kaplan, A.M. If you love something, let it go mobile: Mobile marketing and mobile social media $4 \times 4$. Bus. Horiz. 2012, 55, 129-139. [CrossRef]

61. Mirchev, A.; Dicke, P. Mobile marketing and the usage of a smartphone. Mark. Manag. Innov. 2011, 4, 50-54.

62. Škapa, R.; Částek, O. Faktory Ovlivňující Osvojení Mobilních Služeb: Mezikulturní Porovnání, Vývojové Tendence Podnikü; Masarykova univerzita v Brně: Brno, Czech Republic, 2005.

63. Zujewska, B. Guerrilla Marketing a Creative Marketing Method for Start-Ups. Available online: https: //www.theseus.fi/bitstream/handle/10024/89246/Zujewska_Barbara.pdf?sequence=1 (accessed on 16 January 2019).

64. Monzel, M. 99 tipu Pro Úspěšnější Reklamu; Grada Publishing: Praha, Czech Republic, 2009.

65. Baltes, G.; Leibing, I.L. Guerrilla marketing for information services? New Libr. World 2008, 109, 46-55. [CrossRef]

66. Přikrylová, J.; Jahodová, H. Moderní Marketingová Komunikace; Grada Publishing: Praha, Czech Republic, 2010.

67. Matúš, J.; Petranová, D. Aktuálne Marketingové Trendy v Teórii a Praxi; EDIS: Žilina, Slovakia, 2008.

68. Nadanyiová, M. Global trends of the personnel marketing in service enterprises. In Proceedings of the 16th International Scientific Conference on Globalization and its Socio-Economic Consequences, Rajecke Teplice, Slovakia, 5-6 October 2016.

69. Majerova, J.; Kliestik, T. Brand valuation as an immanent component of brand value building and managing. In Proceedings of the 4th World Conference on Business, Economics and Management, Ephesus, Turkey, 30 April-2 May 2015.

70. Costa-Sánchez, C.; Fontela Baró, B. Corporate communication, marketing, and video games. Stud. Syst. Decis. Control 2019, 154, 421-433. [CrossRef]

71. Lieskovská, V. Vybrané Kapitoly z Marketingovej Komunikácie; Ekonóm: Bratislava, Slovakia, 2002.

72. Hitka, M.; Kozubikova, L.; Potkany, M. Education and gender-based differences in employee motivation. J. Bus. Econ. Manag. 2018, 19, 80-95. [CrossRef] 
73. Hitka, M.; Balazova, Z. Comparison of motivation level of service sector employees in the regions of Slovakia and Austria. Procedia Econ. Financ. 2015, 23, 348-355. [CrossRef]

74. Okazaki, S.; Taylor, C.R. Social media and international advertising: Theoretical challenges and future directions. Int. Mark. Rev. 2013, 30, 56-71. [CrossRef]

75. Abdolmaleki, H.; Zahra, S.M.; Ebrahim, A.G. Identify and prioritise factors affecting sports consumer behaviour in Iran. Int. J. Sport Manag. Mark. 2018, 18, 42-62. [CrossRef]

76. Galvao, M.B.; de Carvalho, R.C.; Oliveira, L.A.B.; Medeiros, D.D. Customer loyalty approach based on CRM for SMEs. J. Bus. Ind. Mark. 2018, 33, 706-716. [CrossRef]

77. Anisimova, T. Integrating multiple factors affecting consumer behavior toward organic foods: The role of healthism, hedonism, and trust in consumer purchase intentions of organic foods. J. Food Prod. Mark. 2016, 22, 809-823. [CrossRef]

78. Delcourt, C.; Gremler, D.D.; Van Riel, A.C.R.; Van Birgelen, M. Effects of perceived employee emotional competence on customer satisfaction and loyalty: The mediating role of rapport. J. Serv. Manag. 2013, 24, 5-24. [CrossRef]

79. Kuzman, M.; Motik, D.; Bičanić, K.; Vlosky, R.; Oblak, L. A comparative analysis of consumer attitudes on the use of wood products in Slovenia and Croatia. Drv. Idustrija 2012, 63, 71-79. [CrossRef]

80. Guha, S.; Harrigan, P.; Soutar, G. Linking social media to customer relationship management (CRM): A qualitative study on SMEs. J. Small Bus. Entrep. 2018, 30, 193-214. [CrossRef]

81. Mészáros, M. Employing' of self-employed persons. Cent. Eur. J. Labour Law Pers. Manag. 2018, 1, 46-67. [CrossRef]

82. Odoom, R.; Anning-Dorson, T.; Acheampong, G. Antecedents of social media usage and performance benefits in small- and medium-sized enterprises (SMEs). J. Enterp. Inf. Manag. 2017, 30, 383-399. [CrossRef]

83. Knoll, J. Advertising in social media: A review of empirical evidence. Int. J. Advert. 2016, 35, $266-300$. [CrossRef]

84. Dessart, L.; Veloutsou, C.; Morgan-Thomas, A. Consumer engagement in online brand communities: A social media perspective. J. Prod. Brand Manag. 2015, 24, 28-42. [CrossRef]

85. Žul'ová, J.; Švec, M.; Madleňák, A. Personality aspects of the employee and their exploration from the GDPR perspective. Cent. Eur. J. Labour Law Pers. Manag. 2018, 1, 68-77. [CrossRef]

86. Kucharčíková, A. Investment in the human capital as the source of economic growth. Period. Polytech. Soc. Manag. Sci. 2014, 22, 29-35. [CrossRef]

87. Ninda Safitri, L.; Sarno, R.; Intani Budiawati, G. Improving business process by evaluating enterprise sustainability indicators using fuzzy rule based classification. In Proceedings of the 2018 International Seminar on Application for Technology of Information and Communication: Creative Technology for Human Life, iSemantic 2018, Universitas Dian Nuswantoro, Semarang, Indonesia, 27 November 2018.

88. Jansson, J.; Nilsson, J.; Modig, F.; Hed Vall, G. Commitment to sustainability in small and medium-sized enterprises: The influence of strategic orientations and management values. Bus. Strategy Environ. 2017, 26, 69-83. [CrossRef]

89. Larsch, S.; Betz, S.; Duboc, L.; Madgaleno, A.M.; Bomfim, C. Integrating sustainability aspects in business process management. Lect. Notes Bus. Inf. Process. 2017, 281, 403-415. [CrossRef]

90. Magdaleno, A.M.; Duboc, L.; Betz, S. How to incorporate sustainability into business process management lifecycle? Lect. Notes Bus. Inf. Process. 2017, 281, 440-443. [CrossRef]

91. Gupta, P.D.; Bhattacharya, S. Impact of knowledge management processes for sustainability of small family businesses: Evidences from the Brassware Sector of Moradabad. J. Inf. Knowl. Manag. 2016, 15. [CrossRef]

92. Pádua, S.I.D.; Jabbour, C.J.C. Promotion and evolution of sustainability performance measurement systems from a perspective of business process management: From a literature review to a pentagonal proposal. Bus. Process Manag. J. 2015, 21, 403-418. [CrossRef]

93. Shkurupska, I.; Litovchenko, I. The development of marketing communications under the influence of the Industry 4.0. Int. Sci. J. Ind. 2016, 1, 103-106.

94. Bettiol, M.; Capestro, M.; Di Maria, E. Industry 4.0: The Strategic Role of Marketing. In Proceedings of the XIV Convegno Annuale SIM, Bergamo, Italy, 26-27 October 2017; pp. 1-7.

95. Pollák, F.; Dorčák, P. The effective use of Facebook by small and medium sized enterprises operating in Slovakia. Trz. Mark. 2016, 28, 79-91. 
96. Hudák, M.; Kianičková, E.; Madleňák, R. The importance of e-mail marketing in e-commerce. Procedia Eng. 2017, 192, 342-347. [CrossRef]

97. Foroudi, P.; Gupta, S.; Nazarian, A.; Duda, M. Digital technology and marketing management capability: Achieving growth in SMEs. Qual. Mark. Res. Int. J. 2017, 20, 230-246. [CrossRef]

98. Ščeulovs, D.; Gaile-Sarkane, E. Impact of e-environment on SMEs business development. Procedia-Soc. Behav. Sci. 2014, 156, 409-413. [CrossRef]

99. Gregori, G.L.; Marinelli, L.; Temperini, V. Využívanie nástrojov digitálneho marketingu v MSP: Potreby, problémy a príležitosti. Empirická štúdia v regióne Marche. Int. J. SalesRetail. Mark. 2015, 4, 69-77.

100. Bačík, R.; Mudrík, M.; Štefko, R.; Kot, S. Analysis of tourism travel trends after 2014. J. Environ. Manag. Tour. 2016, 7, 88-93. [CrossRef]

101. Svoboda, J.; Šalgovičová, J.; Polakovič, A. Religion and tourism in Slovakia. Eur. J. Sci. Theol. 2013, 9, 125-132.

102. Zaušková, A.; Bezáková, Z.; Grib, L. Marketing communication in eco-innovation process. Procedia Econ. Financ. 2015, 34, 670-675. [CrossRef]

103. Nadanyiova, M.; Kicova, E.; Rypakova, M. Green marketing and its exploitation in Slovak companies. Procedia Econ. Financ. 2015, 26, 219-226. [CrossRef]

104. Schüller, D.; Chalupský, V. Marketing communication management of higher education institutions. Acta Univ. Bohem. Merid. 2012, 15, 61-69.

105. Ferencova, M. Investigating possibilities of using tools for promoting higher-education institutions in areas of e-communication. J. Appl. Manag. Investig. 2012, 1, 151-159.

106. Řehák, J.; Brom, O. SPSS—Practical Data Analysis; Computer Press: Brno, Slovakia, 2015.

107. Štarchoň, P.; Vilčeková, L. Evolution of marketing communications in Slovakia. In Proceedings of the 24th EBES Conference, Bangkok, Thailand, 10-12 January 2018.

108. Pohludka, M.; Štverková, H. The best practice of CRM implementation for small- and medium-sized enterprises. Adm. Sci. 2019, 9, 22. [CrossRef]

109. Haviernikova, K.; Ivanova, E. Evaluation of selected risk categories related to marketing activities by SMEs in case of potential cluster cooperation. In Proceedings of the 3rd International Conference on Economic and Business Management (FEBM 2018), Hohhot, China, 20-22 October 2018. [CrossRef]

110. Mura, L.; Mazák, M. Innovative activities of family SMEs: Case study of the Slovak regions. Online J. Model. New Eur. 2018, 27, 132-147. [CrossRef]

111. Lesáková, L.; Gundová, P.; Král, P.; Ondrušová, A. Innovation leaders, modest innovators and non-innovative SMEs in Slovakia: Key factors and barriers of innovation activity. Organizacija 2017, 50, 325-338. [CrossRef]

112. Marková, V.; Sedliačiková, M.; Gurova, D.H. The model of financial budgeting and planning for micro and small enterprises. In Proceedings of the 16th International Scientific Conference on Globalization and its Socio-Economic Consequences, Rajecke Teplice, Slovakia, 5-6 October 2016.

113. Urdzikova, J.; Jakabova, M.; Saniuk, S. The customer relationship management in terms of business practice in Slovakia. Res. Pap. Fac. Mater. Sci. Technol. Slovak Univ. Technol. 2012, 26-34. [CrossRef]

(C) 2019 by the authors. Licensee MDPI, Basel, Switzerland. This article is an open access article distributed under the terms and conditions of the Creative Commons Attribution (CC BY) license (http://creativecommons.org/licenses/by/4.0/). 